\title{
Bill Aitken's : Footloose in the Himalaya : A Saga of "Peak" Experiences
}

\author{
Vijay Prakash Singh \\ Professor of English, \\ University of Lucknow, India
}

From Buddhist Ladakh to Hindu states of Himachal Pradesh and Uttarakhand is a huge geographical stretch to traverse but being the other two Himalayan regions of North India they are significant on the traveller's map and itinerary.

They are a part of Hindu mythology and folklore which is steeped in the snowy peaks of the world's highest range. From Ladakh to Arunachal Pradesh the Himalayan range constitutes a unique bio-diversity that varies from arid desert regions of Ladakh, Lahaul and Spiti in Himachal Pradesh to the lush Alpine regions of Himachal and Uttarakhand to the tropical luxuriance of Sikkim and Arunachal Pradesh. Indian travel writing on the Himalaya is replete with the accounts of one man, an immigrant Scotsman who chose to make the Himalaya his home where he has lived for the past nearly five decades. This is Bill Aitken. Born and brought up in the Ochil Hills of Scotland, Aitken came to India to write a thesis on comparative theology. He visited Calcutta and a chance encounter with Dr. Aravind Basu his thesis examiner led him to Mirtola Ashram in Uttarakhand. However the long sojourn of seven years at the Mirtola ashram occurred only after his visits to Binsar and Kausani. It was in Binsar that overwhelmed with the autumnal allure of the Himalaya Aitken decided to give up his teaching job in Calcutta and his larger plan of pursuing an academic career in Britain and stay back. In his recent book Footloose in the Himalaya Aitken writes, "The Kumaun had determined my choice. Those smug plans to girdle the globe that I imagined would lead to a career in respectable academia were sidetracked by this sensual Himalayan abandonment."(48) It was a moment of epiphany for the young student of comparative theology. The Himalaya held him in its thrall.

Aitken's travelogues of the Uttarakhand, Himachal Pradesh and Ladakh the North Indian regions of the Himalaya are valuable for the element of nature's beauty that he finds in them. His interest in these regions is not anthropological but rather that of a Wordsworthian poet who is enchanted at the multi-faceted dimensions of nature in the Himalaya. Yet while exploring nature through his pleasurable short treks or arduous pursuits of high ranges such as Nandadevi he gives us insights into local culture that are as interesting as those offered by the professional anthropologist. While Himalayan regions like Tibet, Ladakh, Bhutan and Sikkim are Buddhist by faith, Uttarakhand and Himachal have a Hindu culture that marks it as distinct.

Footloose in the Himalaya has been written as a compilation of experiences of four decades of life in the hills. The aim of Aitken's walks in the hills is "to try and hint at the timeless sublimity of the Himalaya even in its lower reaches."(Preface) Indeed walking in the 
lower reaches of the Himalaya is Aitken's supreme pleasure. He describes the walking experience, 'The greatest pleasure from a Himalayan walk is to experience the soft contrasting contours of green glades that give way to pine-strewn paths signifying a drop in height. The sudden change is delightful especially in reverse when you toil up a hot dry hillside and pass into a cool and moist north face."(80) Aitken takes pleasure in the verdant, lower ranges as well as in the cold, higher regions but it is the fertile lushness of the lower ranges that he savours. Aitken is no mountaineer driven by the urge to vanquish or "conquer" high peaks. Like Lama Govinda his attitude is that of the nature devout, willing to be conquered by the peaks. According to him, "Perhaps the Himalaya is more important for the peak experiences it delivers than the peaks themselves"(Preface) Lama Anagrika is a kindred soul for in The Way of the White Clouds he writes,"The worshipful or religious attitude is not impressed by scientific facts, like figures of altitude, which are foremost in the mind of modern man. Nor is it motivated by the urge to 'conquer' the mountain. Instead of conquering it, the religious-minded man prefers to be conquered by the mountain.......... While the modern man is driven by ambition

and the glorification of his own ego to climb an outstanding mountain and to be the first on top of it, the devotee is more interested in his spiritual uplift than in the physical feat of climbing." (Govinda198) For Aitken, the Himalaya is symbolic of India because like the country they evade definition. In Aitken's own words, "The tonic effect of the Himalaya is as hard to define as India herself: both have the daunting prospect of size, a baffling variety of scene and a complex sociology to be assimilated. What areas I have been able to see are inadequate to allow for any certain conclusions but I can confirm that in most of them I have tasted the same rare elixir...."(10) To the adventurer, nature lover or pilgrim witnessing the magnitude of the

Himalaya is like unlocking "the treasures of our inner being"(10) According to him "India has regarded the Himalaya as the source of her civilizational inspiration and still venerates the timeless figures of the Rishi Munis above those who wave ephemeral flags atop Everest. Greatness in India ........was always defined by control of inner rather than outer forces"(10)

The Himalaya represents a spiritual element that is the essence of India. In a philosophical sense the Himalaya is not merely outward form or appearance that enchants, it stands for all that is sacred and mystical in Hinduism. It is more a pilgrim site than a mere eco-system though even as an eco-system its diversity and richness is fascinating. The pilgrim is called upon to accept the "paradox of aesthetic wealth alongside economic poverty, of reconciling the glory of aliveness with the evenly poised mischance of death."(11) It is the sanctity associated with the Himalaya that fosters the attitude of veneration rather than conquest. Unfortunately mountaineering fosters the spirit of conquest which is devastating for the ecology of the Himalaya. Mountaineering expeditions carry disposable items that are conveniently dumped on the peaks where they lie accumulated. Whether it is the Everest or the Gaumukh glacier the source of the holy Ganges, the accumulation of non-degradable garbage poses a threat to the ecology of the peaks. Aitken's attitude is that of the devotee, the 
pilgrim. Aitken notes, "I have always responded to the village view that we are here as mehman, guests of the gods, visitors on this planet, not proprietors. The need to subdue nature may be a sign of uncertainty about our place in the cosmos."'(15) While the attitude of veneration stems from a deep love of nature, the urge to conquer comes from vanity .

Like the American philosopher Henry David Thoreau, Aitken revels in the joys of manual effort that the hills afford him in his stay at Mirtola as well as Kausani where he lived in ashrams. He regrets man's dependence on machine and gadgetry as well as his disconnectedness from the joy of working at jobs he takes for granted from others such as growing and processing his own food. Aitken writes:

The worst severing for industrial man is his true loss of true time, his divorce from the meaningful motion of the sun. Electricity devised to extend the daylight hours for good works is too often abused for the furthering of idle entertainment. Who but the grossly depraved of ear would prefer the braying of a five star disco to the fluted duet of answering owls? (23)

The robustness involved in growing one's food and the contentment of gathering one's own produce evokes Henry David Thoreau's quiet sojourn at Walden lake where he built his own log hut, grew his own vegetables and lived a life of deeper contentment than the urban life with all its consumerist trappings that even nineteenth century Americans were are used to. Here is Thoreau on the superfluities of modern life:

Most of the luxuries, and many of the so-called comforts of life, are not only indispensable, but positive hindrances to the elevation of mankind. With respect to luxuries and comforts, the wisest have ever lived a more simple and meagre life than the poor. (Thoreau 286)

However there is desecration of landscape and a change in the old ways of life even in the mountains. As an example the artistic heritage of Uttarakhand as manifest in the temples of Jageshwar and Baijnath are a contrast to the crass modernity of contemporary buildings constructed in plains style with a wasteful use of cement and brick. Most of these temple towns now have ugly slum settlements with poor sewage and appalling sanitation. While temples and colonial architecture used mainly the local stone or wood to construct structures that were aesthetically fine and more cost-effective, modern constructions are evident of how hill culture has in the words of Aitken "lost its inspiration"(58) In fact of all the Himalayan states that Aitken has visited he finds that "Kumaun and Garhwal stand out as the poorest in terms of cultural remains"(59) while the Kathmandu valley as well as erstwhile states of Himachal stand out as the richest in quality. While domestic architecture using deodar wood(enduring but ecologically damaging ) in such regions as the Sutlej-Tons area of Garhwal blend aesthetically with the environment, government tourist bungalows as well contemporary local construction is a sad imitation of the PWD style of the plains. This erosion of culture is evident not just in architecture but much more so in dress. In the case of Garhwal for example while the men have by and large retained their traditional Gandhi caps with 
jodhpurs or trousers worn over loose shirts and Nehru jackets the women except for the elderly or those in very remote areas no longer wear the ornate silver jewellery and heavy woollen tunics that they did even two decades ago. Through recent decades most women have simplified their dress to the mainstream sari. According to Aitken in his earlier book The Nanda Devi Affair while men in Kumaon traditionally wear congress caps the women more exposed to plains dress have virtually given up the ghaghra for the sari. Garhwali women no longer wear "the tough black drill but favour a brown woollen blanket traditionally folded back and pinned."(Nanda Devi 25) However language and religious faith seem to be the last bastions of local culture that have stood the test of time.

As far as eating habits are concerned caste considerations govern the cooking of food. For the Brahmin the predominant consideration is that no one but a Brahmin should cook his food or it would be unfit for consumption. Rice is sacred and is anointed on the forehead with the traditional red tika. It is the food preferred over wheat and forms the staple of Kumaon and Garhwal. Yet wheat is also a major staple and one reason for this is obviously the high altitudes the Garhwalis inhabit where rice as a crop cannot grow since it does not ripen much above $6000 \mathrm{ft}$.

Soon after coming to Uttarakhand, Aitken stayed at a Gandhian ashram in Kausani run on true Gandhian lines of austerity by Sarla Behn. Sarla Behn is a staunch Gandhian who often carries her puritanism too far. The ashram runs a school for local girls where Sarla Behn metes out the harshest punishments for the slightest liberty taken by the girls. For being an odd job man at the ashram Aitken gets board and lodging without any payment. Aitken learns how difficult life can be in a hill village with farming as the only source of sustenance yet dependent upon the vagaries of nature as well as the plunder of animals. As it is, cultivable land has to be wrested out of the forest which has adverse ecological effects and this in the steep, rocky terrain of Garhwal is a difficult task. With scant farming and poor indigenous employment opportunities most of Kumaon and Garhwal faces a typical hill predicament: the men are idle and this idleness has been cultivated into leisure activities that are a sheer waste of time. While the women labour like beasts of burden, collecting firewood and fodder, tilling the lands and also looking after home and hearth, the men while away their time at tea-shops gossiping, reading the newspapers or playing carom-board. Yet these women are not cynical about their lot. Aitken writes, "Whatever her poverty the singing cheerfulness of the oppressed village woman of Kumaon confirmed the essential unquenchable joy of life."(35) Aitken points out in The Nanda Devi Affair that "their willingness to go the extra mile showed their infinite inner strength,"(35) Aitken writes, "The mountaineering ladies of the village would return with headloads weighing fifty kilograms, ..........then return ten kilometers at a fast gait, fortified

only with a handful of gram. Their evening would involve milking and bedding down the buffalo, then cooking the evening meal of chapattis and vegetables, if available. Hard work on a harsh diet had not made these exploited women any less maternal."(35) At the heart of the cult of worship of Nanda Devi the highest peak of Uttarakhand, lies the paradox that while the Devi is worshipped by the men as much as the women, ordinary women are treated with scant 
consideration. Aitken writes of the paradoxical status of the hill woman that "though she is viewed as a royal princess in both Kumaon and Garhwal, the Goddess remains an ordinary hill woman who must work the treadmill of dismal custom honoured by the theory of traditional respect but abused in the everyday expression of it."(36)

From the Kausani ashram Aitken goes to visit the Mirtola ashram founded by Monica Chakravathi alias Yashoda Mai the wife Dr. Chakravarthi, the first Indian Vice- Chancellor of University of Lucknow. Aitken visits the ashram to meet Sri Krishna Prem formerly Professor Ronald Nixon, an Englishman teaching English Literature at the University of Lucknow and the foremost disciple of Yashoda Mai. At Mirtola ashram the daily regimen was more hard and frenetic than at Kausani but for Aitken the joy of growing one's own food by the sweat of one's brow is so profound as to compensate for all the difficulties. Indeed Aitken is reprimanded in no uncertain terms for distancing himself from physical labour under the selfdelusion of being an ardent mystic whereas in the opinion of his gurus he is actually an escapist. However despite the difference between the Kausani and Mirtola ashrams, their inmates had the same attitude towards the natural beauty of the Himalayas. While travel and mountain climbing were "luxury pastimes" to Sarala Behn, to Krishna Prem the outer beauty of the snows was merely a manifestation of the divine within. His philosophy was to look within rather than outside for beauty and inspiration. This inward focus that chooses to turn a blind eye at nature's magnificence is an attitude that Aitken finds "hard to digest"(Aitken89). From his disillusionment with these ashram attitudes, Aitken charts out his own path.Yet the power of his gurus Sri Krishna Prem and his disciple- also an Englishman by the name of Alexander Phipps- who received the Hindu name Sri Madhav Ashish hold an influence on Aitken's life to this day for their uncluttered wisdom and practical philosophy of life.

Aitken shows through his own experience the goodness of Garhwali character. A deep faith and devotion to religion, readiness to help others, courtesy to outsiders and a much higher degree of honesty as compared to the plains dweller characterizes the local nature. It is as if the beauty of nature had found a measure of reflection in the local dweller.. However one doesn't have to stretch ones imagination too far to speculate how long -given the profitmotive that rampant tourism breeds-this simplicity of character will remain untarnished. Yet scepticism must not overrule the fact that in a country besmirched by fraud and degradation of moral fibre, the natives of rural Uttarakhand have a degree of straight-forwardness that is unusual. Swami Rama in his book entitled Living with the Himalayan Masters points out that people of the Kumaon and Garhwal Himalaya are so honest that if a pilgrim were to drop his purse on the path it would remain untouched even if he came to look for it weeks later. Swami Rama describes the people of Uttarakhand as simple and honest while being "intelligent, cultured and hospitable."(18)

The nature of tourism is such that it tarnishes the people as much as the place. Take for example the valley of flowers. Ever since this natural haven was discovered by Frank Smythe in 1938 it has caused in Aitken's words a "veritable tourist stampede" much to the desecration of "Smythe's fairy-tale valley which has been trampled to death."(109) The reality that has evaded tourist agencies-many of whom might have barely travelled in the region where they are promoting tourism- is that there are as Aitken points out other regions as beautiful as 
Smythe's valley of flowers. If these places could be known to the tourist agencies, trekkers would visit them rather than exploiting Smythe's discovery. This speaks volumes of the lack of field-survey done by Indian trekkers or guides. Most of what we have by way of charming "hill-stations" is in any case a legacy of English explorers and precious little is done by local corporations to preserve or enhance the natural beauty of these places. Indiscriminate construction and the felling of trees with total disregard to the fragile hill ecology, increasing tourist influx which causes increasing construction of resorts and multi-storied hotels, generation of non-degradable garbage and vehicular pollution, fast depleting water resources and the effects of global warming are the major factors responsible for the deterioration of our hill regions. Crude commercialization is fast subsuming the natural beauty of these places.

Uttarakhand is justifiably the "dev bhumi" or land of the Gods since it is the land of not one but four major pilgrimages or the "char dham" apart from scores of other lesser known pilgrimages. Out of the major four pilgrimages of Kedarnath dedicated to Shiva, Badrinath dedicated to Vishnu, Gangotri dedicated to Ganga and Yamunotri to Yamuna, it is Kedarnath according to Aitken, which "represents the essence of the char-dham experience"(134). While Badrinath which is easily accessible by bus has a garish look painted as it is in bright colours, Kedarnath is the "most distinguished of Uttarakhand shrines and the most solid"(136) although it is not more than a few hundred years old. The temples of Jageshwar have a classical design but they date back approximately to a millennium and are believed to have been consecrated by Adi Sankaracharya in the $8^{\text {th }}$ century. Aitken mentions the weather-worn look of the Jageshwar temples. Very similar to Kedarnath in design is Tunganath one of the Panch-Kedar temples but even this seems to be well preserved although the original sanctum sanctorum may be as per mythology of ancient date. It was the Nepalis who in medieval times influenced the culture of Uttarakhand. Tantric rituals and the sacrifice of animals and alcohol as offering to the Gods are a clear Nepali influence. There is also a history of ritual suicide and human sacrifice in fertility rites in medieval times. The British banned the rather bizarre custom of hanging the consecrated villager by rope so that his blood fertilized the land. Another peculiar ritual of Devi-worship occurs in the Baspa valley of Himachal Pradesh where the Devi is honoured when the harvests are good but punished when the weather turns nasty by being locked away in a tower like a naughty child.

Aitken's forays in the Himalaya cover not just the newly formed state of Uttarakhand but also Himachal Pradesh but his association with Uttarakhand is such that he has a far closer affinity to Kumaon and Garhwal than to Himachal Pradesh. Aitken describes Garhwal "as possessing the most beautiful scenery in the Himalaya."(154) Aitken does not find Himachal as spectacular as Garhwal. In language characteristic of his writing style, he describes the appeal of Garhwal, "The perpendicular appeal of Garhwal is due to a more sensuous arousal where shaggy forest and shattered cliff combine in a heroic handshake against the background noise of drumming torrents."(155) While he finds parts of Himachal arid, Garhwal has forests and high altitude meadows known in local parlance as "buggials" along with the snowy range that gives the landscape a variety that is unsurpassable. In his forays in Himachal, Aitken notes the opulence of the palaces of Himachal's Maharajahs which have gone to ruin for want of maintainance. Along with princely palaces, Kangra in Himachal is famed for its distinctive 
school of miniature painting. A noteworthy fact that Aitken points to is that by and large in the Hindu Himalaya the lack of an artistic tradition is due to the low caste hierarchy of the artisan. Aitken contrasts this with the rich artistic traditions of Buddhist Himalayan cultures like Zanskar, Spiti, Sikkim and Ladakh where painting and architecture has flourished for centuries in monasteries and gompas. Aitken visits the Roerich art gallery at Naggar fort where he finds that the Russian master's paintings have "a power and authenticity in his vision of the Himalaya that seems like a gift given only to him"(197) Two other painters who Aitken refers to are Serbjeet Singh and Ram Nath Pasricha. Pasricha's paintings authentically capture the spirit of Himalayan landscapes and faces. He has published a collection of his paintings and sketches with short travelogues to go with them entitled Himalayan Travels: Sketch Book of a Painter published by the National Book Trust.

In Ladakh, Aitken finds the landscape "pristine and surrealistic"(187) and the visitor is cast as if under a physical spell and there is " a tingle of expectancy in viewing the landscape: enlightenment seems at hand"(187). However as in the lower Himalaya the beauty of the landscape is at odds with the living conditions of the inhabitants who only have tourism to fall back upon. Aitken finds Buddhist Ladakh more adapting to adverse conditions than the Islamic areas. The cultural contrasts between the Shia Muslim regions of Kargil to the Buddhist interiors are so drastic as to be inconceivable within such a short distance. The dress and manners of the Shia women are awkward and shy as compared to the outgoing and free manner of the Buddhist women.

Aitken is one of those environmentally conscious travel writers who believe that when travel writers write about the places they visit they bring the attention of tourists to those places. More and more tourists mean more and more ecological damage- in terms of the influx of more automobiles and non-degradable garbage like polythene and plastic. Garbage disposal in most Himalayan hill-stations remain sadly inadequate if not inefficient. Instead of recycling organic wastes through the simple cost-free means of digging manure pits tourist refuse lies dumped on hillsides in the vicinity of government tourist resorts. Until recently an upmarket hill-station like Nainital had its lake getting choked with non-degradable refuse like plastic bottles and snack packets when it could have been prevented by the simple expedient of banning the tourists from carrying any bottles or food packets when boating on the lake. Aitken writes, "Responsible trekking involves keeping our eyes open to every aspect of environmental health and treading with a respect for the ecosystem and the cultural traditions that have grown out of it."(Footloose 249) For him preserving Himalayan ecology is as imperative as vanquishing the peaks is for the aggressive mountaineer for whom the mountains are a challenge to the ego.

Aitken is a nature lover more than an anthropologist. His travelogues are not anthropological in nature. Yet the insights and understanding he has gained into Himalayan culture living in the Himalaya for over four decades is far more realistic than that of the itinerant traveler. Aitken is that marvelous combination of travel writer who is an adventurer, nature-lover and cultural historian. While Nanda Devi Affair is largely adventure travel 
writing, Seven Sacred Rivers and Divining the Deccan are as much cultural explorations as adventure. Footloose in the Himalaya with its collection of travels in Kumaon, Garhwal, Himachal and Ladakh is a synthesis of the vision of the nature lover and the adventurer.

\section{Works Cited}

Aitken, Bill.The Nanda Devi Affair.New Delhi: Penguin Books India,1994. Footloose in the Himalaya.New Delhi:Permanent Black,2003.

Govinda, Lama Anagrika.The Way of the White Clouds. London:Rider \&Co.ltd 2006.

Rama,Swami. Living with the Himalayan Masters.Pennsylvania: The Himalayan Institute Press,1999.

Thoreau, Henry David .Walden and Resistance to Civil Government ed. William Rossi. New York \& London: W.W.Norton,1992. 